\title{
Q2 製品開発の実際
}

\section{酢・新製品開発と現状}

昨今, 食酢業界においても原料の多様化が進み, 新規食酢類は約 40種類にも及ぷという。しかし, 安易な発想による新製品や, 単に 原料が珍しいだけの製品では需要は永続きしない。

本稿では数多くの新規食酢類のうち, 主として健康イメージを重 視した原料による新製品の開発事例について紹介いただいた。

筆者のアンケート調査では, 消費者は食酢に関してもっと各種の 情報提供を望んでいるとの結果がでているが,これは食酢に限らず 広く䤑造食品全般に通じる消費者の要求ではなかろうか。

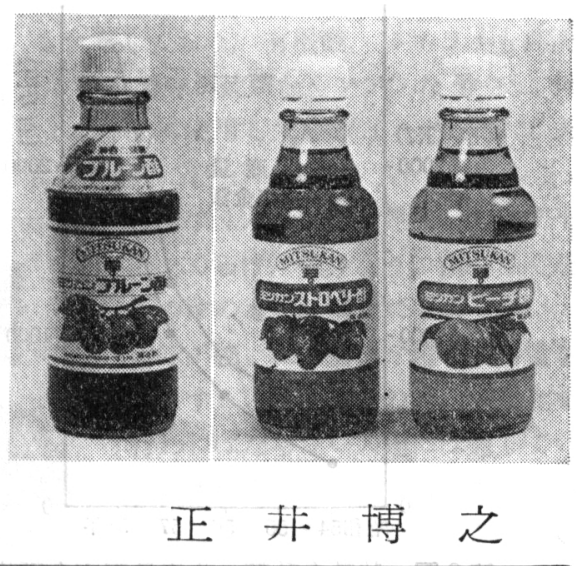

\section{はじめに}

我が国で食酶醇造業が確立されたのは，江戸時代に入 ってからであるといわれている。主に清酒から造られた 米酢であった。その後文化元年 (1804 年) に, 清酒の副 産物である酒粕を使用した粕酢が創案され，当時江戸で 大流行したにぎりずしに赤酢として賞用され米酢と共に 日本を代表する食酢となった。明治 37 年にアルコール が食酢醇造原料に使用されるよらになり, 更に大正 4 年 に合成酷酸工業が起り, その使用による合成酢が誕生し た。第二次世界大戦中から戦後の混乱期の物資欠乏時代 を経て, 昭和 45 年 3 月 10 日の食酢の公正取引規約の 制定, 昭和 54 年 6 月 8 日の食酢の農林規格法の施行を 経て, 食酢業界も漸く安定期に入り, 現在は最も爛熟し た時期であるともいえる。このように本業界も時代の変 暧と共に変化し, 種々の変革を遂げて来た。ここでは, この 10 年来に食酢業界に拈いて開発された食酢の新製 品開発の現状と新たに市場に登場した食酢の一端を紹介 することとする。

\section{1. 食酢の生産概況}

主要調味料の消費が，鈍化，低迷している中で食酢は 年々 3 4\% の增加で推移している。第 1 図は過去 10 年間つ種類別生産量をまとめたものである。とりわけ, 米酿果実酢（主にリンゴ酢）の高級酢の伸びが著しい。 特に眧和 54 年から米酭の生産量の伸びが著しいのは, JAS を契機に, 各食酢メーカーが, 品質的にすぐれた内 容の食酢を生産しあったことと, 消費者がより美味しい 食酢を求めあったこと, この時期に健康イメージを強く 訴求した “くろ酢”之称する玄米踬が台頭し, 消費者の 健康を意識する傾向が高くなった結果である。

このようなことから総務庁の家計調査結果でも, 昭和
51 年度一世帯当り 2.68 立/年の消費量で, 683 円/年の 支出金額が, 昭和 59 年度にには 2.97 立/年の消費量で 1.1 倍の増加率に対し, 支出金額は 1,196 円/年とな り, 約 1.8 倍の支出増となっている。

\section{2. 特殊食酢類の台頭とその実}

農林水産省が経済調查会に委託したニュータイプ加工 食品の生産, 流通等の実態調査報告書の中に特殊食酢類 がとりあげられ，昭和 60 年 3 月に報告書にまとめられ ている。

これら特殊食酢類とは, 健康志向食品として脚光を浴 びるよらになった “くろ酢”と称される玄米酢などで 1 本 2,000 円から 5,000 円といら異常な高価格で売られ ている食酢のことである。

この “くろ酢”といわれる食眽は, 主に鹿児島県姶良 郡福山町を中心に 150 年前に製造が行われた米酢のこ とである。蒸米と楼と水を $2 \sim 3$ 年のさつま焼のツボに 入れ，ふたをして屋外に放置し約 2 力月間で食酢を造っ た。仕込後 1 週間で糖化, アルコール発酵が起り, その 後徐々に酢化が生じ, 約 2 力月でほぽ食酢が出来る。本

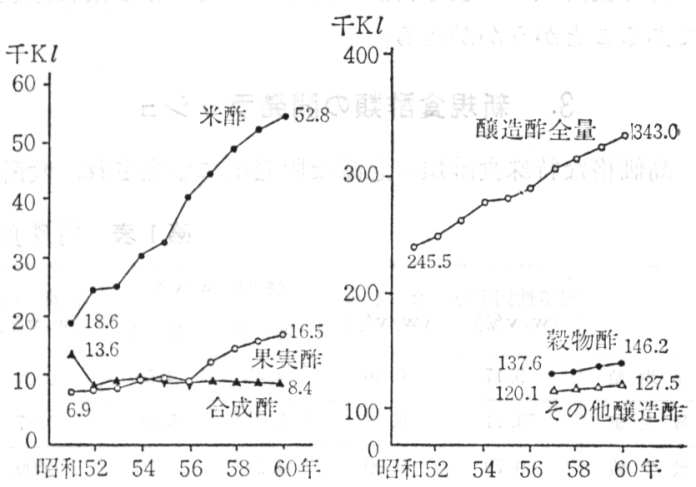

第1図 食酢の種類別生産量推移 


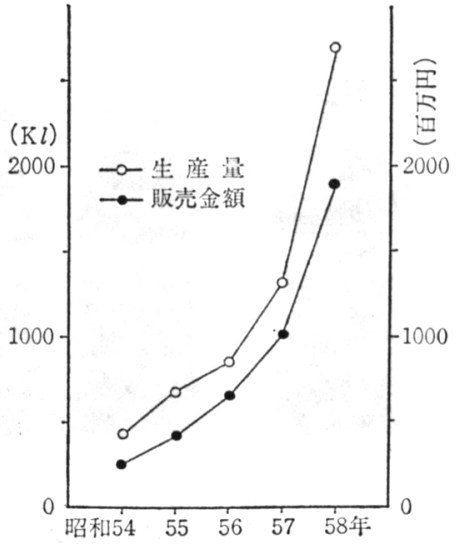

第 2 図 特殊食酢類の生産量販売金額推移 (ニュータイプ加工食品の生産, 流通等の実態調查報告書より)

来は更に大カメ中にて約 3 年間熟成を行い，その間にア ミノカーボニル反応汇より, 褐変, 黒色化した酢にかぎ り “くろ酢”之称したといわれている。このような食酢 は，鹿児島県を中心核をン（食酢のこと）と称して特 産品として発展して来たものである。

昭和 41 年頃に, この特殊食酢類を, 特殊販売ルート で，全国的に発売するメーカーがあらわれ，健康食品と して，また特殊な薬効をうたい，高価格で売り大きな利 益を得るようになり，鹿児島を中心にその追従を行うメ 一カーが多くなった。

昭和 54 年から 58 年にかけてこれら特殊食酢類の生 産量, 売り上げ金額の推移を第 2 図に示した。 5 年間に 生産量は 6.3 倍, 売り上げ金額は 7.2 倍という急激な 上昇を示している。

これら特殊食酢類は, 自然環境の中でのカメ造りと成 分としてアミノ酸含量が高いことをセールスポイントに しているが，その成分は千差万別であり，すべてメーカ 一がカメ仕込みで行っているとは考兄られない。第 1 表 恃特殊食酶類の一般分析値であるが，実汇雑多な成分値 であることがうかがえる。

\section{3. 新規食酢類の開発ラッシュ}

高価格な特殊食酢類の急激な販売增汇触発され，食眽
第 2 表 新規食酢類りスト（カッニ内は銘柄数, 他 1 種類 1 銘柄)

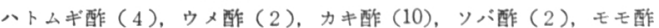
(2), 八チミッ酭, 黒糖酢, プロティン酢, 玄米酢, コンプ酢, タフ

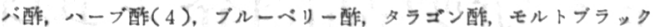
酢, キダチフロエ酢, ダイズ黒酢, シソ酢, デーツ酢, トマト酢(2),

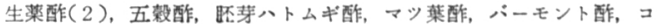

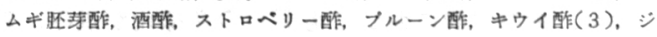

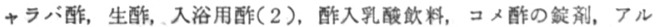

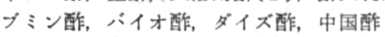

メーカーは勿論, 新規参入の企業や団体がより品質的に 勝り, 付加価值があり, 健康イメージのある新規食酷の 商品開発が昭和 50 年代つ末に発生している。

昭和 57 年から 61 年 5 月末までの約 4 年間の日本経 済新聞の NEEDS-IR のデータベースを使用して新聞記 事に登場した新規食酶と，筆者自身が集めた新規食酶類 をあわせたりストが第 2 表である。39 鲕類 62 銘柄の新 規食酢が登場したことになる。

これら新規食䣷類はあまりにも数が多く, その製法の 実態は定かではない。現在の JAS 規格から考光て, 糖 質の多いものは, アルコール発酵後酶酸発醉をしてお りまたアルコール発酵をせずアルコールを添加使用し て酶酸発酵をしたもの, 更にそ机らの中間的なものが考 えられる。

我が社は社是として“買う身になって, 真心こめて, 良い品を”をモットーにして営業活動を行って来た。ま たよりよい品を, いつでも, どこでも, 安心して, 安定 的に, 上り安く買っていたたくことを大切に, 生産, 販 売して来た。この主旨に沿って我が社が開発して来た食

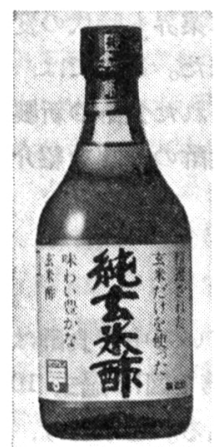
酢を中心に以下にその特徵を紹介す ることとする。

純玄米䣫 $(500 \mathrm{~m} l, 450$ 円)

消費者の健康食品が顕在化し, そ の中で各種の玄米酢もブームとなっ ている。しかし市販されている玄米 酢はあまりにも高価格であり, 品質 的にもバラッキが大きい。そこで, 高品質で, かつ求めやすい洒格であ って，どこででも購入していただけ るようにしたいと考兄, 純玄米が発

第 1 表 特殊食酢類の成分分析結果

\begin{tabular}{|c|c|c|c|c|c|c|c|c|c|c|c|c|}
\hline & \multirow{2}{*}{$\begin{array}{c}\text { 可溶性固形分 } \\
(\mathrm{w} / \mathrm{v} \%)\end{array}$} & \multirow{2}{*}{$\begin{array}{l}\text { 食塩分 } \\
(\mathrm{w} / \mathrm{v} \%)\end{array}$} & \multicolumn{2}{|c|}{ 酸度 $(\mathrm{w} / \mathrm{v} \%)$} & \multirow{2}{*}{$\begin{array}{c}\text { 不揮 発酸 } \\
(w / v \%)\end{array}$} & \multirow{2}{*}{$\begin{array}{l}\text { 全＼cjkstart榶 } \\
(\mathrm{w} / \mathrm{v} \%)\end{array}$} & \multirow{2}{*}{$\begin{array}{l}\text { 全宦素 } \\
(\mathrm{w} / \mathrm{v} \%)\end{array}$} & \multirow{2}{*}{$\begin{array}{c}\text { アルコール分 } \\
(\mathrm{v} / \mathrm{v} \%)\end{array}$} & \multicolumn{2}{|c|}{ 内容 量 $(\mathrm{m} l)$} & \multirow{2}{*}{$\begin{array}{l}\text { 沈 } \\
\text { 段 } \\
\text { 物 }\end{array}$} & \multirow{2}{*}{$\begin{array}{l}\text { 力 } \\
5 \\
2 \\
\text { M }\end{array}$} \\
\hline & & & 表 示 & 測 定 & & & & & 表＼cjkstart示 & 测 定 & & \\
\hline 平均 値 & 5.17 & 0.06 & 4. 45 & 4.53 & 0.24 & 3. 72 & 0.12 & 0.28 & 718.75 & 730.7 & & 132 \\
\hline 最大 値 & 53.11 & 0.38 & 5.0 & 5.06 & 0.87 & 48.44 & 0.30 & 1.11 & 1,000 & $1,015.5$ & 点点 & 点点 \\
\hline 最 少 值 & 0.79 & 0.00 & 4. 2 & 2. 70 & 0.09 & 0.03 & 0.04 & 0.04 & 500 & 510.4 & 中出 & 中出 \\
\hline
\end{tabular}

特殊食酢類 13 点, 一般酢 3 点, 計 16 点の平均 
売された。

本品は精白米を使用した純米酢とは異なり, 原料に精 選した玄米のみを使用して䁔造したものである。

製法は米酢と同様であり，玄米を蒸煮し，自動製赖装 置で䊝を造り, 蒸煮した玄米之共に加水後, 糖化, アル コール発醉し, 酶酸発酵したものである。

純米酢は, アミノ酸含量が $100 \mathrm{mg} \%$ 前後であるが, 本品は $500 \mathrm{mg} \%$ といら高い含量である。巷でいわ机る くろ酶等の品質のよいものでも $450 \mathrm{mg} \%$ で, 内容の貧 弱なものでは $100 \mathrm{mg} \%$ を切るものもある。したがって 本品は, アミノ酸ばかりでなく, 他の有機酸等の成分も くろ酢以上の成分となっている。また, くろ酰と比較し た各種生理効果の基礎実験でもくろ酷以上の効果が確認 されている。

比較的く世も少なく, 香りもさわやかで, すし, すの もの, ドレッシングにも使用出来る。アミノ酸含量が高 いため, 领用の習慣の西る人には, その緩衡作用のため 酢酸の刺战が少なく、、イルドな味でのどごしがよい。

純はとむき酻 $(500 \mathrm{~m} l, 450$ 円)

純玄米酢の好評に応えて, 純はとさぎ酢が商品化され た。

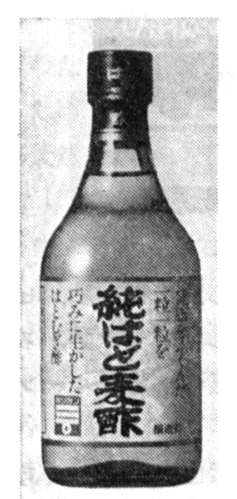

はとむぎは，漢名で琴茨(よくい) といい, 漢法治療に使われたのは, その種子で慧茨化 (よくいにん) と 呼ばれだ。中国で最も古い医薬書で ある「神農本草経」(200 300) に は, 琽茨には, 上薬に分類され,「軽 身, 益気, 不老延年」, つまり健康 を保持增進し、いうまでも若さを保 つことを目的とする薬とされてい た。日本でも古くからはとむぎが茶 等として愛用されて来た。このよう に健康イメージの高いは挝さぎの を使用して、純玄米酶同様の方法で造ったのが純はとむ ぎ酢である。

本品は、はともざ由来のアミ, 酸含量が高く 600 $\mathrm{mg} \%$ と純玄米酢以上の含量であり, 調理は勿論, 飲用 としてもおいしく召上ることが出来る。

純小麦胚芽酢 $(500 \mathrm{~m} l, 700$ 円)

小麦種子中に占める泼芽の割合は, 約 $2 \%$ 程度といわ れているが, 発芽の際に幼根や子葉となり, 生命力の中 心としてもっとも重要な部分である。したがって, 含有 成分も濃厚であり, 高カロリ一源として脂肪, お上び生 命活動に必要なたん白質, 各種の醭素, ビタミン, ミネ ラルなど多量含んでいる。

このような栄養豊富な小麦肧芽の及から造った新しい
タイプの食酢である。小麦肧芽から由来するアミノ酸が $2,000 \mathrm{mg} \%$ も含有して拉り, 有機酸, ミネラルも高濃 度に含まれている。香味が比類なくソフトな酷で, 料 理, 飲用にストレートに使用してもマイルドな酢であ る。

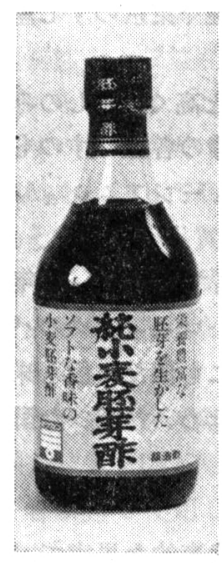

もずく, わかめ, 昆布, しらす干 し、くらげ,きゅうり,にんじんな どのすのもの, 焼魚にもよくあい, 旨味が強いため醬油や塩の使用量を 減らすことが出来るので, 減塩食を 行わねぱならない人達には適してい る。また高含有アミノ酸のためどの 食酢よりも緩衡作用が強いため, 飲 用の習慣のある人, 飲用を試みても 酸の刺戟が苦手といら人には喜ばれ ている。

小麦肧芽から由来する成分により， 色が濃く、醬油に近い色を呈してい る。十分に精製, 沪過, 殺菌しているが, 開栓後に二次 沈溊や，らるみが出るので泠暗所に保存するよう找願い している。

純酒粕酢 (三ッ判山吹) $(900 \mathrm{~m} l, 730$ 円)

本品は, 我が社の創業者である初代中埜又左衛門によ り創案された酒粕からの酢である。従って新製品とはい い難いが, 戦中, 戦後の物資欠乏の混乱期に一時製造が 中断さ祅，十年前に初代の百年忌を記念して再現したも のである。当初限定販売品として, 著名な百貨店にて販

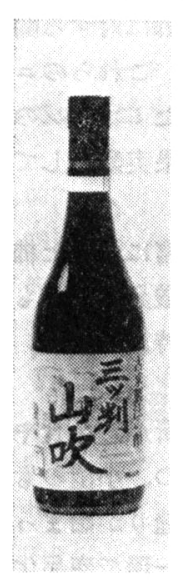
売されたが, 宣伝も余り行わなかったた め, 徐々に店頭から姿を消してしまっ た。昨年末に, 本社, 半田工場にオープ ンした博物館「酢の里」はこの粕酢造り の古い醸造設備を展示したもので, 見学 者の要望により博物館内のミュージアム ショップで希望者に売っている。非常に 評判がよいので, リバイバル商品として 紹介しょうと思う。

文化元年 (1804 年) 初代中埜又左衛門 は, 当時知多酒または中国酒として, 灘, 伏見に次ぐ酒造場であった半田の清 酒粕を利用して酢造りをはじめた。酒粕 を 3 年間, 大桶の中で密閉町蔵し, その間に熟成汇より 白色の酒粕は八丁味噌に近い赤褐色を呈し, アミノ酸は 約 3 倍, 糖分が約 10 倍近くに增加する。この旨味の強 くなった熟成粕と水のみで食酢を造り尾州半田の赤酢と して売り出した。この粕酢は, 当時江戸で大流行したに ぎりずしのための瞃として特汇賞用され，甘味一切使 
用することなく塩のみで合せ酢を作り，シャリに打ら， 新鮮な魚介の味をより引きたてたといわれている。こん なことから, 半田で造った粕酢の半数以上が東京に運ば れ，にぎりずし専用酢として，今日にいたっている。こ の粕酢は, 米酢洨べ旨味が強く, 非常に美味しい酢で あり, 今も江戸時代からの伝統を受け継ぐ東京のすし屋 で半田の赤眽として用いられている。

本品はアミ，酸含量が $1,000 \mathrm{mg} \%$ と高く，すしの及 でなく、きゅらりもみ,わかめ, たこ等の各種のすのも のに用いてもすばらしく美味しく、ミュージアムショッ プの目玉商品としてょく売れている。

この粕酢は, 三ッ判山吹といら商品名であるが, 10 年 前に再現した時, 坂口謹一郎博士より, コニャックのパ ラダイス（100 年もののコニャック）にも似た, 色も味 も香もよくられたすばらしい老酢とお泳めいただいた酢 で，日本を代表する食酢の一つである。

純柿酢 $(500 \mathrm{~m} l, 900$ 円)

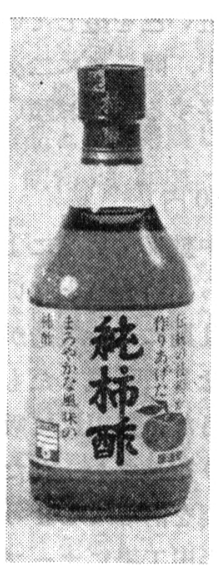

杮は，我が国の代表的な果実で, その品種も 800～1,000 種あるとい われ，古くから日本人になじ文深い 果実の一つである。柿から酸を造つ たといら記録は，最も古い我が国の 特許公報にも記載されていた記憶が あり、今にはじまったものではない。 柿は古くから二日酔いによいとか， 高血圧にもよいといわれて扮り，健 康イメージの強い果実である。食生 活の多様化が進み，食酸に対する関 心の高まっている現在, これらの二 一ズに応党るべく，またミッカンの 純シリーズのバラェティ化の一環として, 果実酢として 初めての純柿酢が商品化された。

果実の中でもカりウムやビタミンCを豊富に含んだ柿 果汁のみを使用し, アルコール発醅後, 釄酸発醅したも ので、ほのかな柿の香りとあろやかな味が特徴である。 すのものや，领用汇適している。

国内に预いては, 各県の農協, 食品試験所が, 生食や 干し柿に不適な摘果したもの, 形の悪いもの, 小型のも の等が沢山出るためそれらの再利用で柿酶造りが始まっ ている。今はやりの一村一品村起し運動の一環で商品化 が進められており，最も製造者の多い酢である。

果実酢四種 (プルーン酢 ( $200 \mathrm{~m} l 220$ 円), ミカン酶 (200 $\mathrm{m} l 180$ 円), ピーチ酢 $(200 \mathrm{~m} l 300$ 円), ストロベ y一酢 $(200 \mathrm{~m} l 300 \mathrm{~m})$ )。

食生活の洋風化, 多様化する中で, 洋酷として去, リ ンゴ酢，ブドウ酢の二品しか商品化されていない。とこ
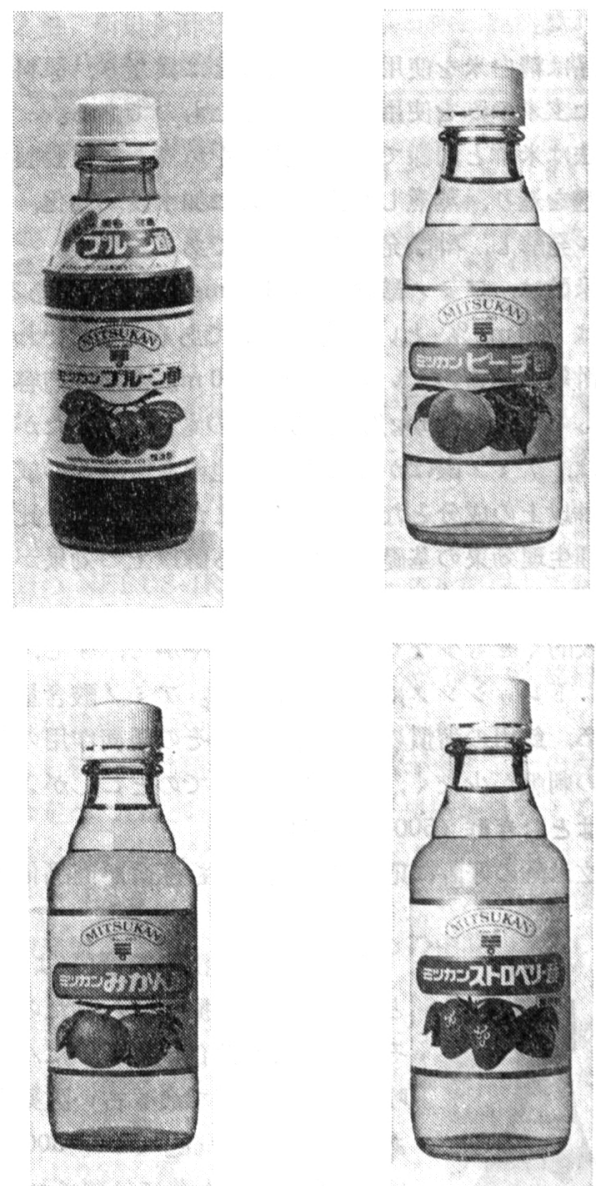

で日本を代表するミカン果汁を原料としたミカン酢, ピ 一チ果汁，ストロベリ一果汁を原料としたピーチ酢， ス トロベリー眽, また最近若い女性に人気のあるプルーン 酶が商品化されている。

プルーンは西洋すももの一種で浱赤紫色の果実で西 る。原産はカスピ海沿岸であるが, 現在はカルフォルニ ヤで全世界の $70 \%$ が生産されている。プルーンは他の 果実と比べ, ビタミン, ミネラルが豊富で, とりわ汁力 リウム, カルンウム, 鉄, ビタミン $\mathrm{A}$, ビタミン $\mathrm{B}$ 群が 多い。そのため貧血, 便秘改善にとりわけ効果があると いわれ，若い女性を中心に評判のよい果実である。

いずれも，それぞれのフルーッの香りが豊かで，マイ ルドな風味をもったフルーツビネガーであり, リンゴ䣫 の代りに蜂蜜を入れたバーモント・ドリンクやフルーツ サラダのドレッンングペースに最適である。

洋風すしに，ストロベリ一酢で合せ酢を作り，モダン な洋風チラシを作って好評だったといら括客様からの便 りをいただいている。いろいろとオリジナルなメニュー 開発を敃楽しみいただける酢である。 

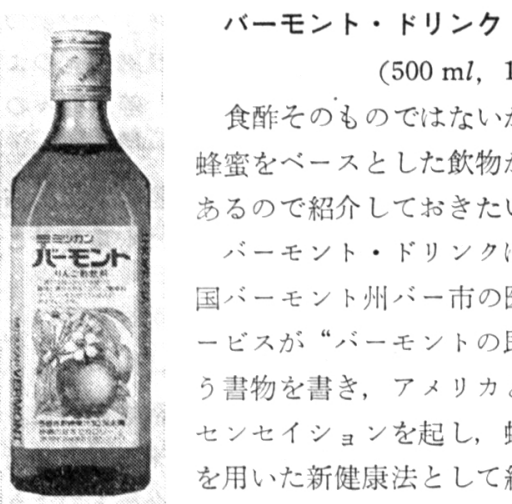

(500 ml, 1, 000 円)

食酢そのものではないが，りんご酢と 蜂蜜をべースとした飲物が大変な評判で あるので紹介して拉きたい。

バーモント・ドリンクは, 1957 年に米 国バーモント州バー市の医師 D.C.ジャ

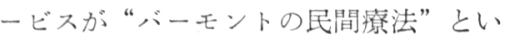
ら書物を書き，アメリカとヨーロッパで センセイションを起し, 蜂蜜とリンゴ酢 を用いた新健康法として紹介された。

我が国では 1961 年にダイヤモンド社 で大原武夫氏の訳で日本語版が出版され，いち早く各種 女性週刊誌がとりあげ評判となった。

当時すでにバーモント・ドリンクとして売り出したメ 一カーもあったが, 何回かのリハイイバを経て, 最近再 び本ドリンクが市場に登場するよらになった。

我が社のバーモントは，リンゴ酢を主体に，プルーン

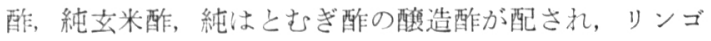
界汁, はらみつ, 有機酸, ミネラル, ビタミン類が配合 され，栄湌のバランスも加味されている。その他アロエ

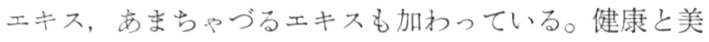
客のために糖分の撕取過剩が気にかかる人々も増克てい ろため, このニーズにあわせて, カロリーを抑壳るため に天然甘味料ステビヤを使い, 甘味度に対してカロリー は $1 / 2$ に押光た商品設計がなされている。そのため飲み 心地はライトな甘さとソフトな酸味のさっぱりとした飲 又易い味わいに仕上っている。

本品を 5 〜 倍の冷水に希釈领用するか, 炭酸水や冷 い牛乳で希釈しても更においしく召し上ることが出来 る。姉妹品として, 天然甘味料ステビヤの使用量を多く したライトカロリーバーモント, りんご酢の代りに玄米 酢のみ老使用した立米酰ドリンクも発売している。いず れも肥満の心配する人々やダイェットを心掛けたい人々 のために, 飲用時 $100 \mathrm{~m} l$ 当り 5 カロリーといらカロリ 一に商品設計がされている。

更に，水での希釈の不便をなくしたバーモント・スト レート二種類（標準バーモント，ライトカロリーバーモ ント）が $1,000 \mathrm{ml}$ 入の紙容器で新発売されている。本 ストレートタイプは, 賞味期間を製造後 3 力月としてい る。

これらパーモント・ドリンクの大手 3 社は, 日本鉣泉 (ラ・バモント), 武田薬品 (プラスバーモント), ミッカ ン（パーモント）で3社で約 $50 \%$ 市場占有率である。 明和 61 年度の総売上げ金額は 67 億円であった。今後 ますます伸びる可能性がある。

\section{4. 新製品開発と情報提供, メニュー提案の 必要性}

以上述べたように数多くの食酢の新製品が市場に出廻 ったが，そろそろ一服の感も出ている。

このような新製品開発は, メーカーサイドにとっては 需要扗大, 収益性向上に貢献して来たが, 反面一般消費 者にとっては，この様に多種に亘る食酢をどのように利 用すべきか選択に迷らケースがある。従って開発した新 食酢を永続して商品として定着させていくためには, 商 品そのものが品質的にすぐれたものであることは当然で あるが，その商品が何に使らのが最も適しているのか， その商品の特徵を明確にとら觉て消費者に提案する必要 がある。

我が社が最近実施した，消費者の食酢に対する意向の 調査結果を以下紹介する。

各家庭で使用している「みそ」「ソース」「ケチャッ プ」「マヨネーズ」そして「食酢」の基礎調味料について 関心のあるものを挙げてもらった。

「最も関心のある」調味料は, 東京, 大阪共に「しょう ゆ」「みそ」の順, 続いて「マヨネーズ」「食釄」となつ ていた。ところが今後ふやしたい調味料となると、「食 酢」が群を抜いて圧倒的に多くなっているのが第 3 図か ら判る。他の調味料がいずれも数\%の割合であるのに比 ベて,「食酢」の増加意向は $30 \%$ 前後と非常に高いこと が注目される。

ところが，これ程高い増加意向にあるにもかかわらず 実際の消費量が急増しないのは「食酢」を使ったメ二ュ ーのレパートリーが少ないということが大きな理由にな っていることが判明した。
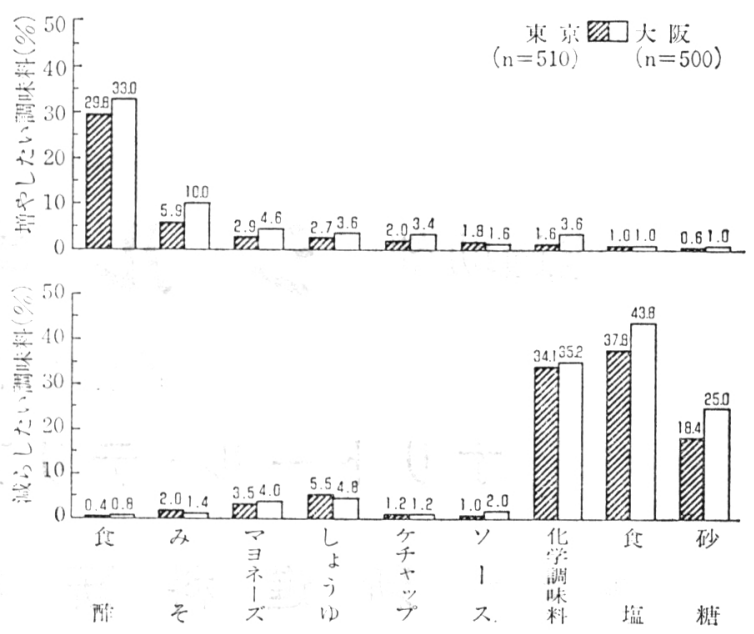

第3図 増やしたい/減らしたい調味料 


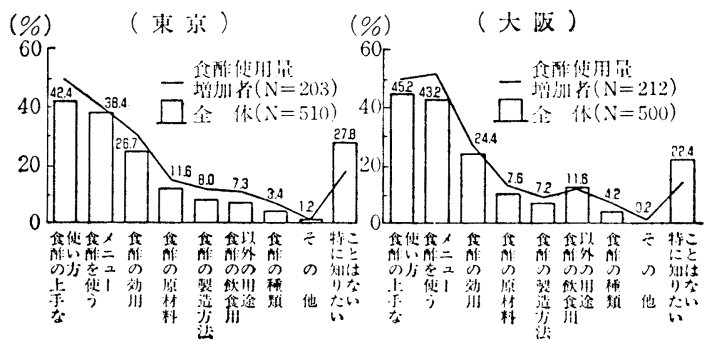

第4図 食酢についての知りたい情報

第 4 図は食酢について消費者が知りたい情報をまとめ たものである。東京，大阪でも $70 \%$ 強の人が何らかの 情報を欲している。

特に何が知りたいかというと「食酢の上手な使い方」 「食酢を使うメニュー」等, 食酢を料理に使う場合の“応 用方法”について関心が集まっているのが目立ってい る。

我が社では昭和 56 年より, 季節の種々の果物と食 酢，砂糖で，梅酒のように手作りで楽しむサワードリン
クを，昭和 58 年に各種の残り野菜で減塩タイブの湞物 であるサワー漬けを，昭和 60 年には，サラダ感覚のよ うに楽しく作っていただく“サワーライス”等, 種々つ メニュー提案をして来た。

今後も更に幅広くこの種のメニュ一提案, 情報提供 が, 新商品開発と同時に, 需要払大のためにも重要なこ とであると考えられる。

\section{おわりに}

食酢の新商品開発の現況を述べ，その特徵を述べた。 食酢は, あらゆる款物, 果物から製造出来るため, 新 商品開発にかげりが見えて来たとはいえ，今後どのよう な新食酢が登場するか子予断は許されない。

新食酢はいずれも原料由来の特徵が出ているものでな ければならない。そのことが，永続的に墭品として生き 残る条件であり，安易な考兵で開発しても一時的なカゲ ロウのようなものになってしまうと思う。また，異常な 高值で売ることも商品の特徵から考えて反省すべき点で ある。

(〈株〉中禁酰浇)

\section{(濾過助剂) シルキーエイド}

滓下剤は信頼と品質の

$$
\text { オリトール・テリアップ・サケライト }
$$

\section{造元 新 進 科 研 (株) 群馬県前橋南五代町 679-3}

